International Journal of Advanced Geosciences, $2(2)(2014) 48-52$
International Journal of Advanced Geosciences
JPC
Journal home page: www.sciencepubco.com/index.php/IJAG
doi: $10.14419 /$ ijag.v2i2.2294
Research Paper

\title{
Evaluation of drinking water quality index (DWQI) and its seasonal variations in hard rock aquifers of Madurai district, Tamilnadu
}

\author{
C. Thivya *, S. Chidambaram, R. Thilagavathi, M. Nepolian, VS. Adithya \\ Department of Earth Sciences, Annamalai University, Annamalai Nagar-608002, Tamilnadu \\ *Corresponding author E-mail:thivyac1988@gmail.com
}

\begin{abstract}
Groundwater is an important source of water supply throughout the world. The quantity and the suitability of groundwater for human consumption are determined by its physical, chemical and bacteriological properties. There are several difficulties for the accessibility of groundwater resources in hard rock areas as wide and erratic variation of essential parameters (i.e., fractures, joints, and porosity) characterizes the groundwater system. Madurai district is such one among them with hard rock regions. A study was carried out in this district of Tamil Nadu for four seasons (Pre-Monsoon, Southwest monsoon, North east monsoon and Post-monsoon), India to assess the drinking water quality and their seasonal variations through DWQI (Drinking water quality index). In order to obtain a synoptic view of quality of groundwater for drinking purpose, a total of 216 groundwater samples for four seasons are collected representing the entire district. $\mathrm{pH}$, temperature, TDS and conductivity of the water samples were measured in the field using a portable water-analysis kit. Sampling and analysis was carried out using standard procedures. The physicochemical parameters considered for the Drinking water quality index (DWQI) include $\mathrm{pH}$, TDS, cations such as $\mathrm{Ca}^{2+}, \mathrm{Mg}^{2+}, \mathrm{Na}^{+}$and $\mathrm{K}^{+}$, anions such as $\mathrm{Cl}^{-}, \mathrm{SO}_{4}{ }^{2-}, \mathrm{HCO}_{3}^{-}, \mathrm{F}^{-}$and $\mathrm{NO}_{3}^{-}$, Heavy metals like $\mathrm{U}_{\text {, }}$ $\mathrm{Zn}, \mathrm{Cd}, \mathrm{pb}$ and $\mathrm{Cu}$ were also considered for DWQI. The poor water quality may be due to the presence of excess amounts of TDS, $\mathrm{Na}^{+}$, $\mathrm{HCO}_{3}{ }^{-}$, and $\mathrm{Cl}^{-}$in the study area. The spatial distribution of DWQI indicates that poor quality of drinking water is observed in patches in different regions and it varies according to the seasons. The change in DWQI in the region implies the seasonal variations of monsoon may be due to leaching of ions, weathering and ion exchange processes.
\end{abstract}

Keywords:Drinking Water Quality Index, Weathering, Leaching, Geochemistry.

\section{Introduction}

Traditional assessment of water quality in groundwater consists of comparing the parameters levels with the WHO, BIS, ISI standards based on allocated water use or uses. This type of assessment is simple and detailed, but not capable to provide a whole and interpreted picture of water quality especially for managers and decision-makers who require concise information about water bodies. To solve this problem, several water quality indices have been developed for water quality parameter levels to an integrated indicator value. A drinking water quality index (DWQI) describes the general situation of groundwater bodies by changing water quality parameters levels into a numerical score using mathematical tools (Boyacioglu 2007; Icaga2007; Ocampo-Duque et al. 2006; Silvert 2000).

The dependence on groundwater has increased tremendously in recent years in many parts of India. Hence, physico-chemical analysis of water is important to assess the quality of groundwater that influences the suitability of water for domestic, irrigation, and industrial needs (Prasanna et al. 2011; Thilagavathi et al. 2012; Chidambaram et al. 2011; Singaraja et al 2013). Because of the importance of groundwater in drinking purposes a study has been conducted in Madurai district to assess the drinking water quality index.

\section{Study area}

The study area is situated in the southern part of Tamil Nadu state bordered by Dindigul and Trichirapalli districts in the north, Sivagangai on the East, Theni on the west, and Virudhunagar district on the south covering an area of about 3,741 sq km (Fig. 1) covering about 2.09 per cent of the total geographical area of the State. It lies between north Latitude of $9^{\circ} 30^{\prime} .00$ and $10^{\circ} 30^{\prime} .00$ and East Longtitude of $77^{\circ} 00^{\prime}$ and $78^{\circ} 30^{\prime}$.The climate is subtropical and the temperature varies from 15 to $41^{\circ} \mathrm{C}$ in the district. The relative humidity varies from 45 to $85 \%$ and is high during $\mathrm{NE}$ monsoon. Geological formations of the study area ranging from Archean to recent. The Archean formations comprise of the Khondalite,_Charnockite, and Garnitiferous_Granulite Biotite Gneisses, Fissile Hornblende Biotite_Gneisses group of rocks (Thivya et al 2013a \& b). The district is underlain predominantly by crystalline formations and alluvium is found along the courses of the river. Ground water occurs under phreatic conditions in weathered residuum and interconnected shallow fractures and under semi-confined to confined conditions in deeper fractures. 


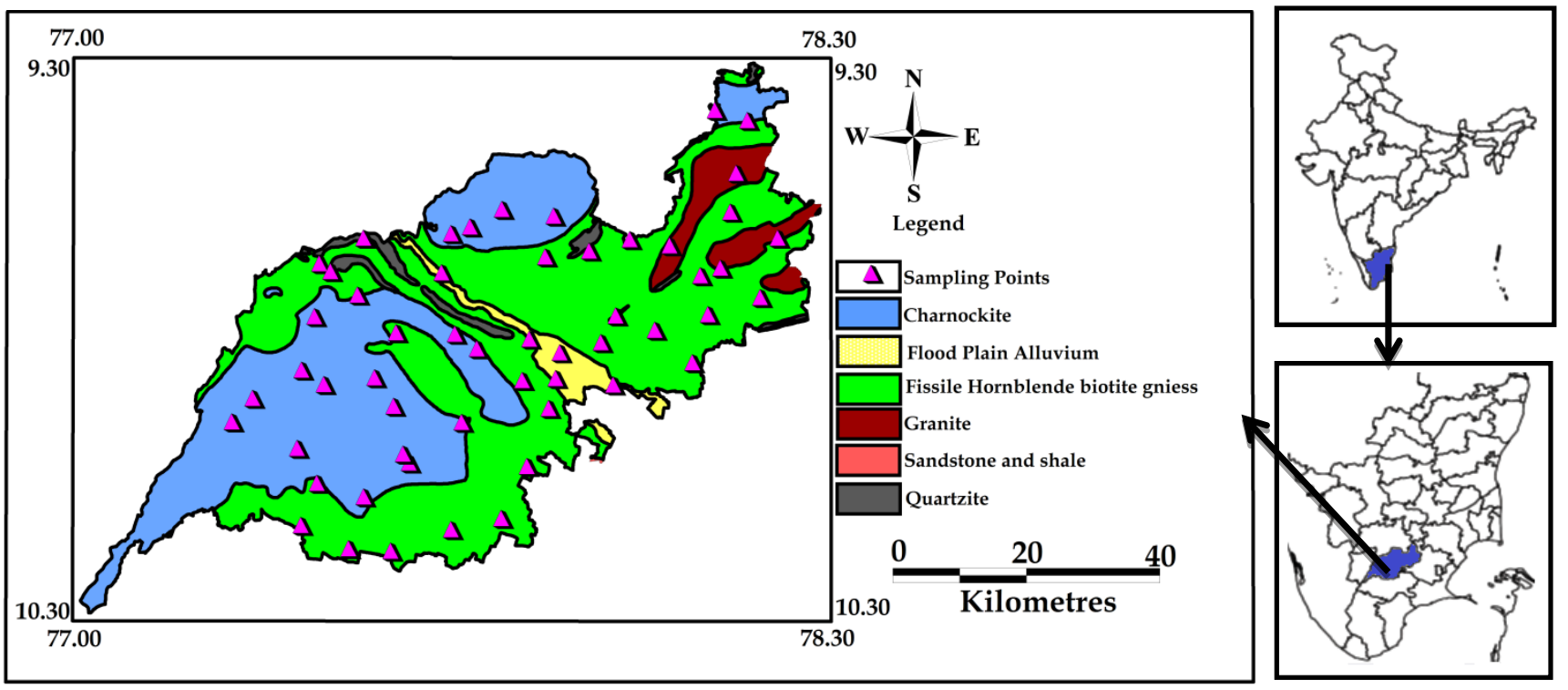

Fig. 1:Lithology and Location points of the study area with sampling points

\section{Methodology}

A total of about 216 water samples were collected from hand pumps representing the entire district during the Pre monsoon (PRM), South west monsoon (SWM), North east monsoon (NEM) and Post monsoon (POM). The $\mathrm{pH}$, temperature, TDS and conductivity of the water samples were measured in the field using a portable water-analysis kit. Sampling and analysis was carried out using standard procedures (APHA 1998, Ramanathan 1992; Ramesh and Anbu 1996).Uranium was analyzed by the Laser fluorimeter and radon is analysed by the RAD7detector.Calcium, magnesium, bicarbonate, and chloride were determined by ti- trimetric method. Sodium and potassium were analyzed through flame photometry (ELICO CL 378). Silica, phosphate, and sulfate were determined by spectrophotometry (ELICO SL 171 minispec). The reliability of the results was determined by the ionic balance of groundwater samples and a 5-10\% of percentage error was noted.

\section{Results and discussions}

The maximum, minimum, and average values of groundwater chemical constituents are given in Table 1 .

Table 1: Maximum, minimum and average of the chemical constituents in groundwater representing all four sampling seasons (All values in mgl ${ }^{-1}$ except $\mathrm{EC}$ in $\mu \mathrm{scm}^{-1}$ and $\mathrm{pH}$.)

\begin{tabular}{|c|c|c|c|c|c|c|c|c|c|c|c|c|}
\hline Statistics & PRM & & & SWM & & & NEM & & & POM & & \\
\hline Parameters & Max & Min & Avg & Max & Min & Avg & Max & Min & Avg & Max & Min & Avg \\
\hline $\mathrm{pH}$ & 8.20 & 6.60 & 7.45 & 8.00 & 5.20 & 7.03 & 8.50 & 6.20 & 7.11 & 7.83 & 6.12 & 7.21 \\
\hline TDS & 1855.43 & 281.70 & 640.16 & 3223.00 & 96.40 & 980.40 & 3500.00 & 78.90 & 1001.46 & 3340.00 & 68.90 & 998.50 \\
\hline $\mathrm{EC}$ & 2900.00 & 441.00 & 1000.64 & 5033.00 & 130.90 & 1532.98 & 6850.00 & 132.40 & 1815.00 & 5218.75 & 107.66 & 1630.02 \\
\hline Temperature $\left({ }^{0} \mathrm{C}\right)$ & 36.50 & 26.50 & 31.78 & 33.30 & 28.63 & 31.42 & 32.70 & 27.50 & 30.79 & 34.10 & 29.80 & 31.70 \\
\hline $\mathrm{Ca}^{2+}$ & 276.00 & 20.00 & 77.13 & 552.00 & 12.00 & 122.99 & 156.00 & 8.00 & 42.27 & 294.00 & 32.00 & 80.20 \\
\hline $\mathrm{Mg}^{2+}$ & 98.40 & 1.20 & 18.45 & 214.00 & 9.60 & 46.30 & 216.00 & 2.40 & 38.82 & 131.00 & 10.00 & 33.77 \\
\hline $\mathrm{Na}^{+}$ & 312.00 & 18.00 & 106.31 & 412.00 & 18.00 & 123.96 & 716.00 & 19.00 & 145.34 & 654.00 & 19.00 & 132.81 \\
\hline $\mathrm{K}^{+}$ & 147.20 & 2.40 & 40.87 & 162.00 & 6.00 & 30.29 & 137.00 & 3.00 & 25.59 & 98.90 & 3.70 & 25.63 \\
\hline $\mathrm{F}^{-}$ & 1.96 & 0.17 & 0.52 & 2.17 & 0.14 & 0.68 & 2.12 & 0.10 & 0.73 & 2.68 & 0.12 & 0.62 \\
\hline $\mathrm{Cl}^{-}$ & 925.00 & 35.00 & 181.18 & 2144.73 & 35.45 & 371.92 & 1843.40 & 17.73 & 332.79 & 1637.71 & 35.30 & 294.69 \\
\hline $\mathrm{HCO}_{3}^{-}$ & 439.20 & 109.80 & 269.05 & 475.80 & 73.20 & 341.04 & 390.40 & 12.20 & 157.70 & 435.13 & 120.53 & 256.13 \\
\hline $\mathrm{NO}_{3}^{-}$ & 372.50 & 1.90 & 100.42 & 377.50 & 0.20 & 114.31 & 261.25 & 0.01 & 60.59 & 322.50 & 0.85 & 96.89 \\
\hline $\mathrm{PO}_{4}^{3-}$ & 3.50 & BDL & 0.29 & 2.30 & 0.01 & 0.26 & 12.50 & BDL & 0.73 & 4.98 & 0.03 & 0.41 \\
\hline $\mathrm{SO}_{4}^{2-}$ & 100.00 & 12.00 & 30.98 & 40.20 & 0.00 & 10.76 & 17.50 & 2.50 & 5.57 & 38.07 & 6.52 & 15.50 \\
\hline $\mathrm{H}_{4} \mathrm{SiO}_{4}$ & 72.00 & 2.50 & 46.57 & 172.00 & 2.00 & 84.33 & 129.50 & 8.00 & 114.35 & 113.33 & 4.17 & 81.71 \\
\hline $\mathrm{U}$ & 113.00 & 0.20 & 6.21 & 156.84 & 0.56 & 7.39 & 46.70 & 1.17 & 6.72 & 116.32 & 1.28 & 8.21 \\
\hline${ }^{222} \mathrm{Rn}$ & 123.00 & BDL & 9.15 & 59.95 & BDL & 7.81 & 211.60 & BDL & 10.17 & 98.26 & BDL & 8.18 \\
\hline
\end{tabular}

\subsection{Drinking water quality index}

Water quality index is a rating, reflecting the composite influence of water quality parameters. The quality of groundwater for drinking purpose is assessed using the drinking water quality index (DWQI). The index was computed by assigning weights (w) to the water quality parameters (a) based on their perceived threat to water quality. This is achieved by translating the constituent concentrations into a single value that reflects the composite influence of water quality parameters. The relative weight (Wa) is computed using

$$
\mathrm{W}_{\mathrm{a}}=\frac{\mathrm{W}_{\mathrm{a}}}{\sum_{\mathrm{a}=1}^{\mathrm{n}} \mathrm{w}_{\mathrm{a}}}
$$

Where $\mathrm{Wa}=$ weight of water quality parameter $\mathrm{a}$ and $\mathrm{n}=$ number of parameters. The quality parameters were assigned weights (Wa) in a scale of 1-5 based on their importance and role in the determination of drinking water quality as presented in Table. 2 . The maximum weight of 5 was assigned to $\mathrm{pH}$ and total dissolved solids due to their major importance in drinking water quality assessment Bicarbonate was assigned a weight of 1 as it is not very significant in the water quality assessment, as it does not influence drinking 
water quality in the study area. Other parameters were assigned weights between 1 and 4 based on their importance in the water quality evaluation of the region (modified from Ramakrishnaiah et al. 2009 and Vasanthavigar et al. 2010).

Table 2: Weights of parameters and WHO Standards (mg/L) for all seasons

\begin{tabular}{|c|c|c|c|c|c|c|c|c|c|}
\hline & \multicolumn{2}{|l|}{ PRM } & \multicolumn{2}{|l|}{ SWM } & \multicolumn{2}{|l|}{ NEM } & \multicolumn{2}{|l|}{ POM } & \multirow{2}{*}{$\begin{array}{l}\text { WHO standard } \\
(2004)\end{array}$} \\
\hline & Weight & Relative weight & Weight & Relative weight & Weight & Relative weight & Weight & Relative weight & \\
\hline $\mathrm{Ca}$ & 3 & 0.08 & 3 & 0.08 & 3 & 0.08 & 3 & 0.08 & 75 \\
\hline $\mathrm{Na}$ & 2 & 0.05 & 2 & 0.05 & 3 & 0.08 & 2 & 0.05 & 200 \\
\hline $\mathrm{K}$ & 2 & 0.05 & 2 & 0.05 & 2 & 0.05 & 2 & 0.05 & 20 \\
\hline $\mathrm{F}$ & 2 & 0.05 & 2 & 0.05 & 2 & 0.05 & 2 & 0.05 & 1 \\
\hline $\mathrm{Cl}$ & 4 & 0.11 & 4 & 0.11 & 4 & 0.11 & 4 & 0.11 & 200 \\
\hline $\mathrm{NO}_{3}$ & 4 & 0.11 & 4 & 0.11 & 3 & 0.08 & 4 & 0.11 & 50 \\
\hline $\mathrm{SO} 4$ & 1 & 0.03 & 1 & 0.03 & 1 & 0.03 & 1 & 0.03 & 200 \\
\hline $\mathrm{HCO}_{3}$ & 1 & 0.03 & 1 & 0.03 & 1 & 0.03 & 1 & 0.03 & 350 \\
\hline $\mathrm{U}$ & 2 & 0.05 & 3 & 0.08 & 2 & 0.05 & 2 & 0.05 & 0.015 \\
\hline $\mathrm{Cu}$ & 1 & 0.03 & 1 & 0.03 & 1 & 0.03 & 1 & 0.03 & 0.005 \\
\hline $\mathrm{pb}$ & 1 & 0.03 & 1 & 0.03 & 1 & 0.03 & 1 & 0.03 & 0.0005 \\
\hline $\mathrm{Zn}$ & 1 & 0.03 & 1 & 0.03 & 1 & 0.03 & 1 & 0.03 & 3 \\
\hline $\mathrm{Cd}$ & 1 & 0.03 & 1 & 0.03 & 1 & 0.03 & 1 & 0.03 & 2 \\
\hline $\mathrm{pH}$ & 5 & 0.14 & 5 & 0.13 & 5 & 0.14 & 5 & 0.14 & 8.5 \\
\hline & $\sum \mathrm{w}_{\mathrm{a}}=37$ & $\Sigma \mathrm{W}_{\mathrm{a}}=1$ & $\sum \mathrm{w}_{\mathrm{a}}=38$ & $\Sigma \mathrm{W}_{\mathrm{a}}=1$ & $\Sigma \mathrm{w}_{\mathrm{a}}=37$ & $\Sigma \mathrm{W}_{\mathrm{a}}=1$ & $\Sigma w_{a}=37$ & $\Sigma \mathrm{W}_{\mathrm{a}}=1$ & \\
\hline
\end{tabular}

A quality rating scale $\left(\mathrm{q}_{\mathrm{a}}\right)$ for each parameter was calculated by dividing its concentration in each water sample by

$$
\mathrm{q}_{\mathrm{a}}=\frac{\mathrm{C}_{\mathrm{a}}}{\mathrm{S}_{\mathrm{a}}} \times 100
$$

It's respective WHO standard and is expressed as

Where $C_{a}=$ concentration of water quality parameter (a) in milligrams per liter and $\mathrm{S}_{\mathrm{a}}=\mathrm{WHO}$ standard for water quality parameter (a) in milligrams per liter. The sub index (SI) was determined for each parameter, which is then used to determine the DWQI as follows:

$$
\begin{aligned}
& \mathrm{SI}_{\mathrm{a}}=\mathrm{W}_{\mathrm{a}} \times \mathrm{q}_{\mathrm{a}} \\
& \mathrm{DWQI}=\sum \mathrm{SI}_{\mathrm{a}}
\end{aligned}
$$

The drinking water quality was classified based on DWQI values of less than 1000, 1000-2000, 2000-3000, 3000-4000, and greater than 4000 as excellent, good, poor, very poor, and unsuitable,

\begin{tabular}{|c|c|c|c|c|c|}
\hline DWQI & Category & PRM & SWM & NEM & POM \\
\hline$<1000$ & Excellent & $9 \%$ & $2 \%$ & $13 \%$ & $11 \%$ \\
\hline $1000-2000$ & Good & $28 \%$ & $22 \%$ & $30 \%$ & $26 \%$ \\
\hline $2000-3000$ & Poor & $19 \%$ & $24 \%$ & $22 \%$ & $33 \%$ \\
\hline $3000-4000$ & Very Poor & $22 \%$ & $19 \%$ & $11 \%$ & $13 \%$ \\
\hline$>4000$ & Unsuitable & $22 \%$ & $33 \%$ & $24 \%$ & $17 \%$ \\
\hline
\end{tabular}
respectively (Table.3).

Table 3: Percentage of Samples of DWOI for All Seasons

The DWQI maps of the PRM and SWM revealed that most of the samples in these seasons are dominated by good, poor and very poor categories (Fig.2). In PRM good category drinking water is observed as patches in all parts of the region, very poor category is noted in southern part whereas rest of the region is covered by poor categories. In SWM good and poor category is noted same as in PRM whereas very poor category is observed in NE and southern part may be due to leaching of ions, overexploitation of groundwater, direct discharge of effluents along Vaigai River and agricultural impact (Jasmin and Mallikarjuna 2013). In NEM it ranges from excellent to very poor category whereas in POM it ranges from Excellent to poor category. An increase in the category of good quality water during NEM and POM is mainly due to dilution processes during the monsoon. The poor water quality may be due to the presence of excess amounts of TDS, $\mathrm{Na}^{+}$, $\mathrm{HCO}_{3}{ }^{-}$, and $\mathrm{Cl}^{-}$in the study area.

\section{Mechanism controlling water chemistry}

It is a commonly accepted fact that there is a close relationship between water composition and aquifer (Gibbs 1970). It is a plot of $\left(\mathrm{Na}^{+}+\mathrm{K}^{+}\right) /\left(\mathrm{Na}^{+}+\mathrm{K}^{+}+\mathrm{Ca}^{2+}\right)$ Vs. TDS and $\mathrm{Cl}^{-} /\left(\mathrm{Cl}^{-}+\mathrm{HCO}_{3}^{-}\right)$ Vs. TDS.

Most of the PRM samples falls in weathering and some of the samples falls in precipitation zone. In SWM most of the samples falls in weathering and evaporation regions. In NEM most of the samples falls in boundary between evaporation and weathering regions. In POM most of the samples falls in Weathering zone and some along the boundary between weathering and evaporation zones (Chidambaram et al. 2008; Srinivasamoorthy et al. 2008). Most of the NEM and POM samples fall outside the plot preview indicates the anthropogenic activities. In this plot most of the samples are rock dominance. This might be attributed to chemical weathering of rock forming minerals acting as the major driving force in controlling ground water chemistry (Chowdhury and Srimanta Gupta 2011, Manikandan et al 2011).

The representation of samples in anion ratio most of the PRM samples are dominated by ion exchange processes. In SWM, $\mathrm{HCO}_{3}$ is the dominant anion which is mainly due to weathering or rock water interaction. The higher recharge processes and weathering is dominant in this season whereas in NEM dissolution and leaching processes predominates with increases with TDS. Most of the POM, NEM and SWM samples are observed along the boundary between rock water interaction and evaporation zone suggesting that rock water interaction is dominant in SWM and later it is dominated by anthropogenic processes (i.e.) by chloride during NEM. In POM the samples fall along the border of weathering and evaporative zone reflecting that they are dominated by the mixing processes. 

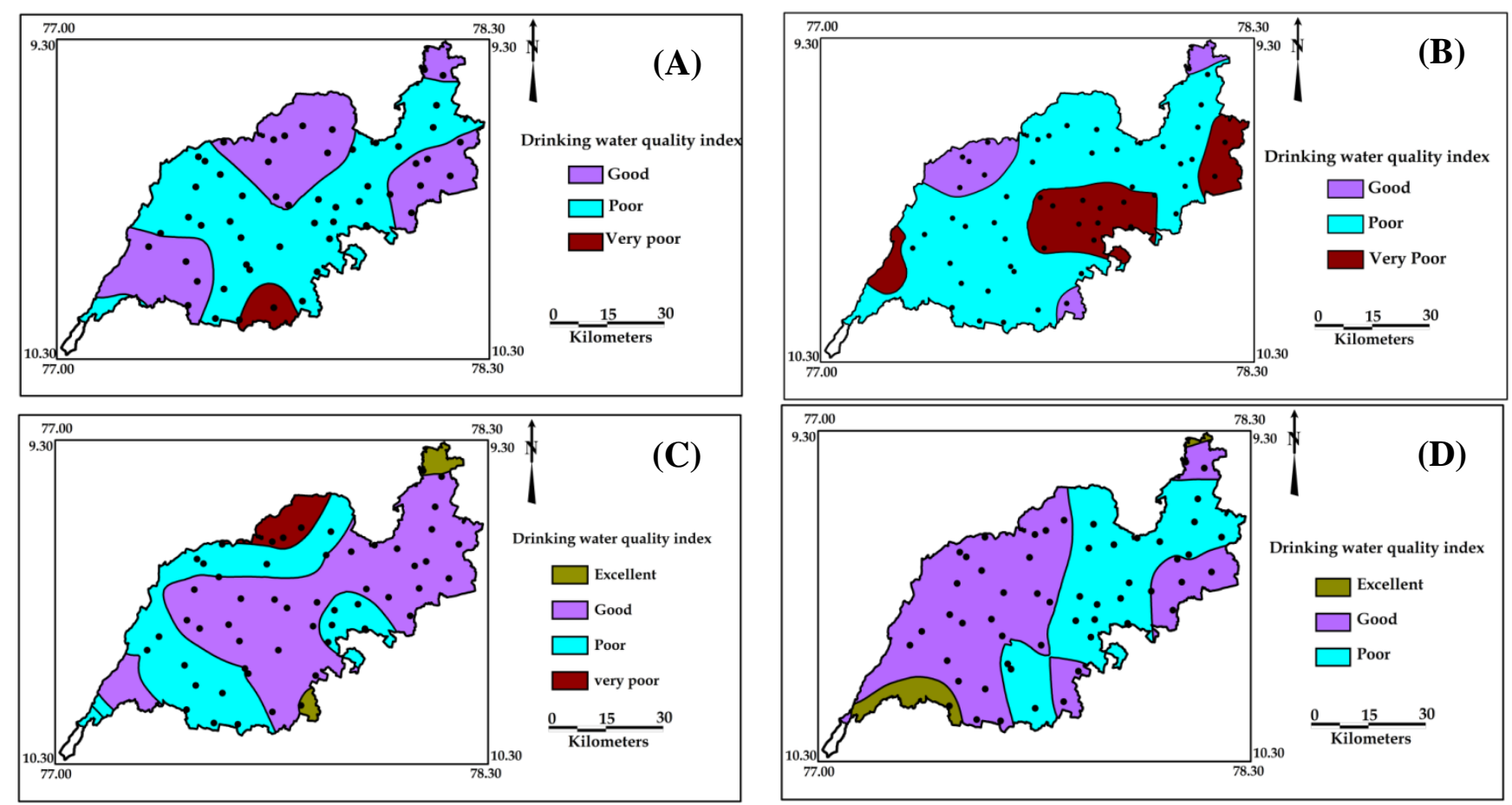

Fig. 2: Spatial distribution of Drinking Water Quality Index for A) PRM, B) SWM, C) NEM and D) POM with sampling points

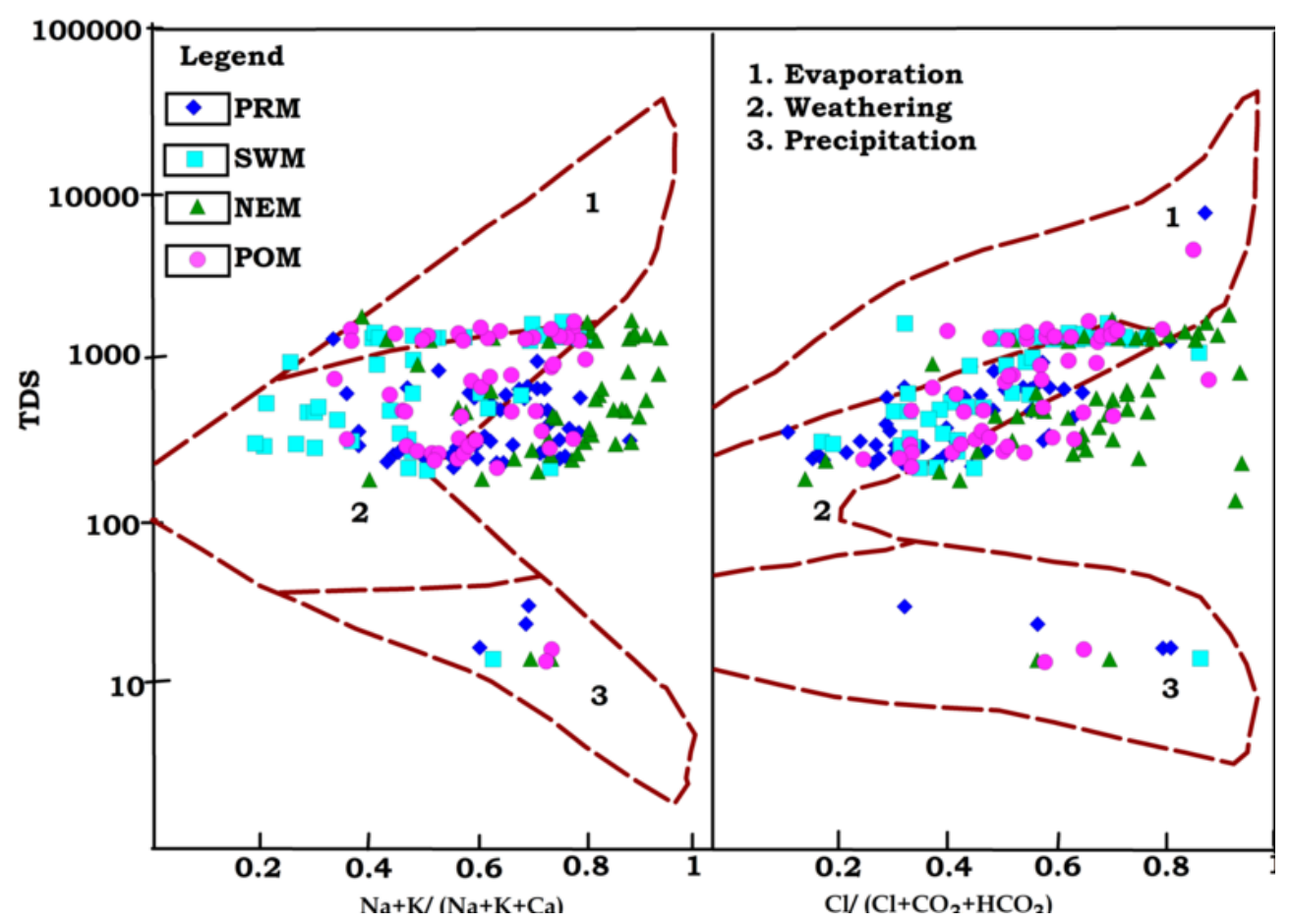

Fig. 3: The mechanism for identification of major process for all seasons (Gibbs 1970)

\section{Conclusion}

The chemical composition of the groundwater in the study area shows that $\mathrm{Cl}^{-}$and $\mathrm{HCO}_{3}^{-}$are the dominant anions and $\mathrm{Ca}^{2+}$ as the dominant cation. The study also brings out the fact that majority of the samples are within the permissible limit and can be used for drinking, domestic and agricultural purposes. The major process responsible for the hydrogeochemistry of the study area is inferred to be as weathering, ion exchange processes. The higher EC is observed along the Vaigai river course due to sewage disposal. There are also anthropogenic influences along the River Vaigai. The water quality of the SWM shows good and poor category is noted in PRM, this very poor category is observed in NE and southern part may be due to leaching of ions, overexploitation of groundwater, direct discharge of effluents along Vaigai river and due to agricultural impact. An increase in the category of good quality water during POM may be due to dilution processes after the monsoon.

\section{Acknowledgments}

The authors wish to express their sincere thanks to University Grants Commission (UGC), India for providing the necessary financial support to carry out this study with vide reference to UGC letter no. F: 39-143/2010 (SR) dated 27 December 2010. 


\section{References}

[1] Boyacioglu H (2007) Development of a water quality index based on a European classification scheme. Water SA 33, 101-106.

[2] Chidambaram S, Karmegam U, Prasanna MV, Sasidhar M, Vasanthavigar M (2011) A study on hydrochemical elucidation of coastal groundwater in and around Kalpakkam region, Southern India. Environ Earth Sci 64(5):1419-1431

[3] Chidambaram S, RamanathanA L, Anandhan P, Srinivasamoorthy K, Prasanna M. V, Vasudevan, S. (2008). A statistical approach to identify the hydrogeochemically active regimes in ground waters of Erode district, Tamilnadu. Asian Journal of Water, Environment and Pollution, 5(3), 123-135.

[4] Gibbs R J (1970) Mechanisms controlling world's water chemistry. Science 170:pp.1088-1090.

[5] Icaga Y (2007) Fuzzy evaluation of water quality classification. Ecol Indic. 7, 710-718.

[6] Jasmin I, Mallikarjuna P (2005) physicochemical quality evaluation of groundwater and development of drinking water quality index for Araniar River Basin, Tamil Nadu, India. Environ Monit Assess DOI 10.1007/s10661-013-3425-7

[7] Manikandan S, Chidambaram S, Prasanna M V, Thivya C, Karmegam U (2011) Hydrochemical Characteristics and GroundwaterQuality Assessment in Krishnagiri District, Tamilnadu, India. International Journal of Earth Sciences and Engineering, Vol. 04, No. 04, , pp. 623-632

[8] Ocampo-Duque W, Ferre-Huquet N, Domingo J L, Schuhmache M(2006) Assessing water quality in rivers with fuzzy inference systems: a case study. Environ. Int. 32, 733-742.

[9] Prasanna MV, Chidambaram S, ShahulHameed A, Srinivasamoorthy K (2011) Hydrogeochemical analysis and evaluation of groundwater quality in the Gadilam river basin, Tamil Nadu, India. J Earth Sci 120(1):85-98

[10]Silvert W (2000) Fuzzy indices of environmental conditions. Ecol. Model. 130,111-119.

[11]Singaraja C, Chidambaram S, Anandhan P, Prasanna MV, Thivya C, Thilagavathi R, Sarathidasan J (2013) Hydrochemistry of groundwater in a coastal region and its repercussion on quality, a case studyThoothukudi district, Tamil Nadu, India Arab J Geosci DOI $10.1007 / \mathrm{s} 12517-012-0794-0$

[12]Srinivasamoorthy K, Chidambaram S, Prasanna M V, Vasanthavigar M, John Peter A, Anandhan P (2008) Identification of major sources controlling Groundwater Chemistry from a hard rock terrain A case study from Metturtaluk, Salem district, Tamilnadu India. Journal of Earth System Sciences, 117(1), 49-58.

[13]Thilagavathi R, Chidambaram S, Prasanna M V, Thivya C, Singaraja C (2012) A study on groundwater geochemistry and water quality in layered aquifers system of Pondicherry region, southeast India. Applied Water Science, 2, 253-269. Doi: 10.1007/s13201-012-0045-2.

[14]Thivya C, Chidambaram S, Singaraja C, Thilagavathi R, Prasanna MV, Jainab I (2013) A study on the significance of lithology in groundwater quality of Madurai district, Tamil Nadu (India). Environ Development Sus. doi:10.1007/s10668-013-9439-z

[15] Thivya C, Chidambaram S, Thilagavathi R, Prasanna MV, Singaraja C, Nepolian M, Sundarrajan M (2013b) Identification of the geochemical processes in groundwater by factor analysis in hard rock aquifers of Madurai district, South India. Arab J Geosci, DOI 10.1007/s12517 013-1065-4.

[16] Vasanthavigar M, Srinivasamoorthy K, Vijayaragavan K, Rajiv Ganthi R, Chidambaram S, Anandhan P (2010) Application of water quality index for ground water quality assessment: Thirumanimuttarm sub-basin, Tamilnadu India. Environmental Monitoring and Assessment, 171(1-4), pp.595-609. 